\title{
IMAGES OF CULTURE: PARTICIPATORY VIDEO, IDENTITY AND EMPOWERMENT.
}

\author{
Peter Anton Zoettl \\ CRIA, Lisbon University Institute ${ }^{1}$
}

\begin{abstract}
Drawing on recent fieldwork in Brazil and Portugal, "participatory video" is critically evaluated as a tool for anthropological research and empowerment. While questions of "image" and "identity" stand out as a major concern of the video workshops discussed, it is suggested that awareness-raising is the ultimate objective of audio-visual methods within a "shared anthropology" that seeks not only to produce scientific knowledge, but also to acquire political relevance.
\end{abstract}

This paper deals with the possibilities and limitations of "participatory video" as an anthropological method for research and representation. While it has been widely used within development studies and projects for quite some time ( $c f$. White 2003), participatory video is still in its infancy as a tool for anthropological fieldwork and as a medium for the representation of anthropological knowledge. This is principally because of the lack of a social sciences framework for the evaluation of most of the participatory video projects which deal (both explicitly and not) with "anthropological" subjects and questions.

In the following pages I will reflect on my own fieldwork with different Portuguesespeaking communities on both sides of the Atlantic, namely Indians in the northeast of Brazil and African immigrants in Lisbon, Portugal. In the course of the workshops I have conducted in these communities, young local people jointly produced short video documentaries, having been introduced to the basic technical and conceptual aspects of film-making. These workshops were partly executed within an organizational framework that went beyond academic and anthropological concerns. For example, a workshop that was organized in a neighbourhood of immigrants of mainly Lusophone African descent - and which resulted in a short piece about local musicians, called Misturas ("Mixtures") - was financed and supervised by a local NGO and by the government body responsible for a large-scale restructuring programme within this area in the outskirts of Lisbon. Here, as elsewhere, the

\footnotetext{
${ }^{1}$ The research for this article has been made possible by a grant of the Portuguese Fundação para a Ciência e a Tecnologia (FCT).
} 
organizational framework had distinct implications for the outcome of the workshop; these will be discussed below.

\section{A tool for empowerment?}

Participatory video is often cited as a tool for "empowerment", mainly within the context of development or human/minority/indigenous rights. Dowmount (2007: 14f) notes that while digital technologies are used across lines of gender, class and other differences, the way they are used continues to reflect socioeconomic disparities. Compared to content consumers, the percentage of (non-professional) content producers is extremely small and, as Dowmount observes, the "availability of the technology by itself does not guarantee that (particularly socially excluded) young people will be able to get access to, or make use of it in productive ways" ( $i b$.). The idea that "he who has the camera, has the power"2 (Bentes 2006: 1) is widespread and is based on the assumption that a lack of public "voice" is one of the main reasons for the low levels of minorities' participation commonly seen in decisionmaking processes. This is of course true, but, it is equally obvious that "giving the camera away" (Ramella and Olmos 2005) does not, in itself, transform "objects" of political action into political actors. Pink has pointed out a certain "tyranny" (my expression) of participation within recent anthropology, where "[t]hose who advocate reflexive methods tend to regard others as having not engaged sufficiently with reflexivity" (2001: 588f).

When working with participatory video (and other participative mediums) obstacles to true "empowerment" are manifold. Gadihoke (2003: 280) points to the power structures that exist within local communities and which can easily dominate participatory projects which set out to promote equal access for "everybody" to the means of audiovisual production. Furthermore, the notion of "community" refers to an analytical concept which does not necessarily correspond to an evident empirical entity, and could, following Bourdieu, be called an "actualized social fiction" (1996 [1994]: 129). As Benedict Anderson has pointed out, "all communities larger than primordial villages of face-to-face contact (and perhaps even these) are imagined" (2006 [1983]: 6), as they embrace, under a common denominator, a variety of different people from often very different socioeconomic, cultural and historic backgrounds. Yet as Anderson emphasizes, communities are not "invented" in the sense that

\footnotetext{
${ }^{2}$ My translation, as elsewhere (unless otherwise stated).
} 
they are merely "fabricated" or "falsified", but are the outcome of a process of communitybuilding in which imagination occupies an important place (ib.).

The intention in itself to hand over audiovisual means to grassroots "communities" in the field can be a difficult task, since local authorities may consider access to technology to be a "question of power" that interferes with the established balance of power within the community. Aside from such practical difficulties, empowerment projects may simply be wrong to assume that their target groups actually suffer from a lack of empowerment. Sahlins (2000: 416ff) and others have advised against the widespread belief that the "world system" has made passive objects out of the majority of non-western peoples. As Gadihoke (2003: 281) puts it, the "problematic assumption in most 'empowerment projects' through video activism is that grass roots people lacked empowerment or voice prior to the introduction of video, and that video would magically 'give voice to the voiceless"'. Bell Hooks, for instance, has affirmed marginality as a "site of resistance", and points out that marginality should not only be seen as "a site of deprivation" but also as "a space of refusal, where one can say no to the colonizer, no to the downpressor" (1990: 341, cf. also Ferguson et al. 1990 or Scott 1985).

Despite all these difficulties and limitations, what can participatory video achieve? The question is twofold, since it refers as much to the benefits participatory video can potentially bring to people who are introduced to, and trained in, audiovisual techniques, as it does to the hoped-for increase in anthropological knowledge (and its filmic representation). I will try to highlight the capabilities and shortcomings of participatory video as a research tool and method of social intervention by providing a short summary of some of the workshops I have recently conducted, pointing out their differences and similarities, whilst attempting to contextualize their outcomes.

\section{Awareness, Image and Identity}

Independent of the subject matter, over the course of all of the workshops I have conducted two aspects have stood out: image and identity. These concepts are closely intertwined, since pictorial images are frequently employed to communicate identity and cultural identity manifests itself (although not exclusively) by means of pictorial and mental images. The idea of empowerment to "give voice" to marginalized people is closely related to the desire of many communities to correct what they experience as an erroneous public image of themselves. Marginalized people not only lack economic resources but usually also the 
power to have a say in how they are seen and depicted by the dominant sectors of society. That is, they lack the power to exercise control over their "image" - a shortcoming which can, in turn, be co-responsible for their underprivileged economic situation (a negative "image" reduces the chances of finding a well-paid job).

In Brazil, the political bargaining position of Indian peoples, especially in the northeast, is severely affected by their negative "image" in a large part of the "white" population. As Melatti noted, Brazilians really appreciate their indigenous population - as long as they do not live in their vicinity. Those who "live close to Indian villages develop a variety of prejudices against them, and commonly treat them with open hostility", while those "who life far away adopt a romantic vision of Indians which, while also prejudiced, is at least sympathetic to them" (2007 [1970]: 267). In a recent article in Veja, one of Brazil's most widely read news magazines (with a mainly middle-class readership), re-emergent indigenous groups $^{3}$ are portrayed as shrewd quick-change artists who assume their Indianness solely for public welfare benefits (Coutinho, Paulin, and Medeiros 2010: 154ff). However absurd these kinds of accusations may be, they reflect widespread convictions within the "white" population and are one cause of the general absence of public support for the demands of Brazilian Indians.

The situation of the Pataxó Hã-Hã-Hãe, who live in the south of the state of Bahia, is a vivid example of the Indian struggle and the many fronts on which this operates. In their fight for land ownership they not only battle, sometimes violently, with farmers who refuse to accept FUNAI's (the state agency for indigenous affairs) demarcation of their territories, but they are also in constant confrontation with state agents (such as the Federal Police and the law courts) and the surrounding population, due to the unresolved legal status of their traditional territory. Although the justice of their claims (at least from an anthropologist's point of view) appears more than evident, public opinion holds the Indians themselves responsible for this conflict. People see them as troublemakers who are claiming something which does not belong to them, rather than earning their living through "proper" work (which means either taking a job in the city or as a contracted agricultural worker on land occupied by farmers). The reason for the poor reputation of the Indians is not only found in the political influence of the economically powerful farmers which affects public opinion (and reaches

\footnotetext{
${ }^{3}$ The Portuguese term emergente ("emergent" or "re-emergent") is widely used to denote Brazilian indigenous groups which had, until recently, ceased to claim their Indianness publicly in order to avoid discrimination ( $c f$. Oliveira 2004). This is criticized by many indigenous leaders since they say it fails to value their decades-long struggle for recognition.
} 
well beyond local administration level), but also in a general lack of knowledge within Brazilian society about the history and situation of the country's indigenous population.

As a result, the recent discovery of funeral urns within the Hã-Hã-Hãe's disputed territory was considered by them to be of utmost importance, since it was felt to be tangible proof of a claim which, for lack of material evidence, had always been difficult to substantiate: that the land they plough was indeed their ancestor's land - and should continue to be theirs today. The heavy urns (which could only be dug out and carried through the joint efforts of a number of men from the village) finally demonstrated - that is, made visible - the legitimacy of their demands. When a team of archaeologists and anthropologists from UFBA, Bahia's state university, arrived to supervise the excavation of the urns, the Hã-Hã-Hãe immediately grasped the importance of the event and filmed both the proceedings and the accompanying ceremony using a small video camera which they had recently acquired from an NGO. As their need to transform their raw material into a distributable film coincided with my need to further develop my research, we agreed to jointly edit the tapes during one of my visits.

The process of editing the Hã-Hã-Hãe's video exemplifies some of the issues I have encountered during many of the participatory workshops I have carried out in Brazil and Portugal. First of all, of the handful of Indians who turned up on the date fixed (with sufficient prior notice, as transport and communications in the area is difficult), only two were actually interested in learning about and performing the "boring" task of film montage, as one of the participants described it. Participatory fieldwork with minority groups in Brazil is severely affected by the history of relations between those groups and the governmental and non-governmental bodies that deal with them. In Brazil, as elsewhere, individuals from minorities that happen to belong to a "target group" seem to develop a kind of "welfare memory" through which former experiences with state agents or NGO workers determine future expectations. Indians or quilombolas (rural communities that affirm their African descent) and black immigrants in Portugal share a common experience: at the very time that they are ill-treated by the state and the general public, they are indulged by other government and non-government agents. While Brazilian Indians may be arbitrarily arrested by the Federal and Military Police, "hunted like game" by gunmen (as one of the native interviewees in the Hã-Hã-Hãe video described it) or despised by a large part of their non-Indian neighbours, they have, on the other hand, become weary of ever-new anthropologists, social workers, or "helpful" travellers spontaneously appearing in their villages. As supply overtakes 
demand, many Indian "customers" are anxious to at least benefit from the monetary byproducts of scientific research or humanitarian action. People rarely see any direct benefit (for themselves) in the doings of anthropologists and social activists, and often only those who have nothing else to do bother to attend the inflated number of workshops that are generally advertised as a way of "reaffirming Indian culture". As one of my informants in the Pataxó village of Aldeia Velha remarked, "We've plenty of projects, but few Indians to run them".

Such a "welfare" framework is, of course, especially problematic from a participatory research perspective, as it is diametrically opposed to the idea of a more than superficially shared anthropology based on an interchange of ideas and experiences. Ultimately, participatory video not only attempts to be an exercise in camera handling and editing techniques, but a "thick" reflection - by the anthropologist and the local participants - of the filmed topoi. As other authors, often drawing on personal experience, have stated, it is not the material outcome (that is, the final film) which makes participatory video workshops worthwhile, but the process that leads to it (cf. White 2003; Ginsburg 2002).

Participatory video workshops could be conceptualised as a contribution to what the Brazilian educator Paulo Freire termed (in 1960s vocabulary) a "pedagogy of the oppressed", a pedagogy that champions the "questioning of man and his relation to the world", in contrast to the mere "deposition of contents" (Freire 2005 [1968]: 45,77). As Freire observes, economically and/or socially marginalized people are particularly exposed to what he calls "cultural invasion", forms of oppression where the dominant groups in society impose their "world view" on the non-dominant sectors (something Bourdieu would later call "symbolic violence"). Education, the principal means of overcoming such "cultural invasion", should not, according to Freire, be thought of as simply a vehicle for vertical knowledge transfer (from the teacher to the student), but as an endeavour to create awareness, an understanding of the world and its relational structures.

Following Freire's educational perspective, the outcome of participatory video projects cannot be measured according to the cinematographic end product - however important that clearly is in terms of motivation and the proper dissemination of a community's concerns. In the case of the Hã-Hã-Hãe video - where my participation as a coeditor was first and foremost intended as "technical assistance" in response to a short-term request by the Indians to help them make their concerns public - the material outcome evidently overshadowed the process. However, the discussions that were consistently provoked by the assembling of the film provided a deeper understanding - for the 
anthropologist and the Indian filmmakers - about the raw material and the situation which engendered it. For instance, a taped statement of one of the Hã-Hã-Hãe leaders, in which he harshly criticised the state agency for Indian affairs, triggered a debate about the real causes of the Hã-Hã-Hãe's unresolved legal situation, as a result of which the leader's statement was rejected as "his private opinion" (and excluded from the edited film).

A workshop I organized in collaboration with another indigenous group in the state of Bahia - the Pataxó of Coroa Vermelha - not only produced a film which was recognised by a wider public, but also serves as an example of how participatory video can help to encourage reflective processes within a community. The video is a filmic encounter between the Pataxó and the tourists who come to visit their Indian village and its adjacent nature reserve. It highlights the tourists' stereotyped view of the locals and also gives expression to concerns about the stereotyped and superficial presentation of Indian culture by the local tourist industry, of which the Pataxó are part.

The video was called Capa de Índio ("Indians in disguise"), in reference to the tourists' mimicking of Indians during souvenir photo sessions. As a matter of fact, the Indians themselves "dress up" on certain occasions when they feel the need to (visually) externalize their Indianness. For north-eastern Indians the use of "traditional" Indian vestments, the performing of Indian rituals or the relearning of Indian languages are all part of an attempt at so-called "cultural reaffirmation" which, to a certain extent, is not devoid of deference to the Other's preconception of "generic" Indianness. The complex relationship between the Other's view, the Indians' self-image, and the felt necessity to act out their Indianness in public frequently emerged during the workshop at Coroa Vermelha. The questioning (literally, through interviews conducted with visitors) of the Other's view, as much as the perception that the Other's notion of Indianness is also a consequence of the way the Pataxó present themselves in public, brought up for discussion the difficulties and pitfalls of north-eastern Indians' on-going process of identity construction.

While in other parts of Brazil indigenous people perform quite naturally, for example, as hip-hop artists, north-eastern Indians usually continue to confine themselves to cultural expressions that neatly correspond to what is considered (by non-Indian Brazilians) to be their "traditions". This adherence to "picturesque" forms of presenting Indianness can in part be traced back to the way Brazilian society officially adopted (and adopts) its indigenous and African heritage within an ideology of a nation of mixed origins and without prejudice ("democracia racial" or "racial democracy"). Manuela da Cunha points out the extent to 
which Brazil's indigenous population formed, throughout history, an integral part of the state's "nationalist imagination" - always preferring those Indians who were either extinct or corresponded to the widespread primitivist image of Brazil's native inhabitants that had already been part of the colonial enterprise (2009: 330f, 191). ${ }^{4}$

\section{Images of culture}

As all of our video "rushes" were regularly screened on the TV sets of relatives and friends of the co-directors, the discussion about Pataxó Indian identity and its representation quickly moved beyond the small group of workshop participants. Distribution of the film to other Indian communities in the area and screenings at festivals or academic gatherings helped to raise the question of Indian identity and the situation of the north-eastern Brazilian Indians beyond the confines of the Pataxó reserve. Capa de Índio might be taken as an example of what Crocker, in his discussion of the "Fogo Process" - one of the earliest experiences in participatory video - called (citing the social psychologist George Herbert Mead) the "division between [...] the $I$ and the $m e$ ", the "understanding of myself and my motives, and other people's image of who and what I am" (Crocker 2003: 131). The Pataxó's self-image and the non-Indian image of how Indians purportedly are, not only visually collided on-camera, but throughout the scripting, filming and editing process, thus obliging workshop participants and tourists (and also the anthropologist) to reconsider their preconceptions about "true" Indianness ( $c f$. Zoettl 2011b).

While the workshops that created the Hã-Hã-Hãe video and Capa de Índio were organized independently of any (non-Indian) institutional framework, the previously mentioned workshop working with second generation African immigrants in Lisbon was set up through my initiative with the local NGO Moinho da Juventude ("Windmill of Youth") and the "Critical Neighbourhoods Initiative" (Iniciativa Bairros Críticos), a programme of the

\footnotetext{
${ }^{4}$ In contrast, Brazil's African roots found much later official recognition as having been constitutive of an autochthonous (that is, post-colonial) Brazilian identity. Today, Afro-Brazilian "cultural manifestations" are, especially in the north-eastern part of the country, promoted as part of the country's cultural showcase, and African ancestry has become legally promoted as ethnicity through the special status attached to descendants of former fugitive slave communities called quilombolas (cf. Zoettl 2011a). Of course, the state's willingness to recognize and incorporate the "cultural riches" of marginalized segments of society does not necessarily imply significant improvements of their socio-economic situation, and may pre-eminently serve as a strategy of nationbuilding. Likewise, the Portuguese colonial government's policy of assimilation was part of a rhetoric that sought to "compensate" the subjugated populations' inferior economic and legal status by recognizing and showcasing its "valores culturais" ("cultural values"), pretending that metropolitan and African citizens were, independent of their "race", an integral part of the Ultramar Português (Portuguese Overseas Empire).
} 
Portuguese Bureau of Regional Planning" which "aims to develop solutions for the improvement of urban spaces that demonstrate characteristics of vulnerability" (IHRU: 2011a). Cova da Moura, the neighbourhood in the outskirts of Lisbon where the workshop took place, is one of three Portuguese suburban areas that were chosen for "socio-territorial action" (ib.), targeting people in situations of economic and educational disadvantage.

In a video posted on the initiative's site, the local project leader Helena Dores defines changing "the image of Cova da Moura" as one of "the central axes of this initiative" (IHRU: 2011 b, original translation). Dores' statement provides a clue as to why audio-visual media projects have become relatively popular within social intervention contexts in recent years. This is not only true for Portugal, where African immigrants and underprivileged nationals are the main target groups for governmental and non-governmental agencies. In Brazil, video workshops - ultimately financed by public money even when organized by NGOs - have flourished in recent years. The visual spin-off of these workshops may be one of the reasons for this development, since the funders usually reserve themselves the right to exploit those images produced in conjunction with funded projects. Images, within this context, are not only understood to potentially be able to improve the negative "image" of marginalized target groups, they are also considered valuable for the public relations of the funding bodies and project administrators.

The workshop I conducted in Cova da Moura took place within a framework in which the desire of community members to learn something useful (or simply entertaining) coincided with the need for the initiative's agents to carry out the project's cultural agenda. The 14-minute video we produced was scripted, filmed and edited by a group of seven residents and highlights the variety of musical styles one can find in Cova da Moura, through the examples of morna (a traditional, romantic style of music from the Cape Verde Islands) and rap. The film's topic was chosen by the workshop participants, with no major influence from the "Critical Neighbourhood" representatives, who attended our first meetings.

Admittedly, I myself would have preferred a more "politically relevant" topic for the video, that is, something more directly related to the everyday problems of the community. Arbitrary police violence with a markedly racist bias, for example, is commonplace in many of the marginalized suburbs of Lisbon, and it is difficult even for the casual visitor not to meet somebody who has a story about this issue. And while the idea of making a documentary about ex-prisoners who originate from the neighbourhood was initially put forward, it was

\footnotetext{
${ }^{5}$ Secretaria de Estado do Ordenamento do Território e Cidades.
} 
eventually dismissed since the participants did not support it as much as the video about musicians.

This "gap" between the political concerns of the fieldworker and the concerns of the community itself has been reported by other participatory practitioners: Padma Guidi (2003: 259), for example, describes how she "tried to push the buttons" in a video workshop with Guatemalan Maya women. Vincent Carelli recalls the reluctance of Brazilian Indians to adopt what he, in the early years of his well-known Video nas Aldeias ("Video in the Villages") project, supposed to be the main purpose of his undertakings:

\footnotetext{
"Eighteen years ago, when I started, my idea was that video would be an instrument of exchange of information, of denunciation... When I was doing fieldwork in a Nambiquara village, timber was being stolen; there was no lack of problems. But they were just not interested, whatsoever, in reporting this: 'We want to film the ear-piercing!' What they wanted me to shoot had nothing to do with what I thought would serve the objective of the film. And that was what I had to understand straight away. That what they were really interested in was filming their cultural riches." (Corrêa 2006a: 12f)
}

Why might Brazilian Indians, Guatemalan indigenous women and Portuguese immigrants of African descent be seemingly equally uninterested in the political potentialities of the new media, to the frustration of the anthropologist or social activist? It shouldn't be forgotten that being eager to show one's "cultural riches" does not necessarily signal an apolitical attitude. The day-to-day survival of minorities is often closely linked to their recognition as a distinct group within society, a status that may call for periodical reaffirmation of whatever is - by the minority and by the Other - considered to be the group's "culture": a truly political undertaking. As Sahlins (1993) observed, "culture" today is one of the weapons non-dominant groups may employ in making a stand against those dominant forces which might eventually threaten their traditional way of being. As Sahlins remarks, while "reified notions of cultural differences" have always existed, the "current 'culturalism' [...] is the claim to one's own mode of existence as a superior value and a political right." More than an "expression of ethnic identity", according to Sahlins, this objectivation of culture reflects "the people's attempt to control their relationships with the dominant society, including control of the technical and political means which up to now have been used to victimize them" (ib.: 4). Indeed, for Brazilian Indians, acknowledgment of their culture (or parts of it) as Indian "culture" (that is, as a communicable, publicly expressible entity) is of vital importance, since it determines their legal status and, subsequently, their legal existence as indigenous people. Demonstrating one's "cultural riches" is therefore not only a means of tracing ethnic boundaries in Barth's (1969) terms, but also of upholding such boundaries as 
part of the group's political negotiation strategy ( $c f$. e. g. Turner 1992 or Comaroff and Comaroff 2009).

\section{Being seen and visualizing}

Being on camera (and, subsequently, on air or online) is not only important for the recognition of a group's culture and identity, it can also be of great relevance to the nondominant sectors of society, simply because of the gain in visibility which may bring people back from oblivion and into public existence. At the same time as the Hã-Hã-Hãe congratulated themselves on the archeological finds from the period of their presumed ancestors, they felt the need to make these finds visible to their fellow non-Indian citizens in order to publicly reaffirm their claim of Indianness. In terms of indigenous politics, nothing could be worse for Brazilian Indians than simply to no longer be noticed, not least because it has often been international attention that has protected them from even worse treatment.

Being visible, or making oneself or somebody visible, is a form of symbolic power comparable to what Bourdieu called the "power of nomination" (e.g. Bourdieu 1996 [1994]). The state and its agents, as well as other institutions (such as the press) not only establish identities by conferring "names" on social groups, they also exercise the power of exhibiting - or masking - certain groups within or from public discourse. Brazilian re-emergent Indians are not only threatened in their "nominal" existence by FUNAI, which exercises the power to "designate", that is, officially recognize them (or not) as what they actually are (indigenous people), but they may also suffer "symbolic violence" (Bourdieu) according to the way in which they are (or are not) publicly discussed. Being depicted either as Brazilians that invent their Indianness for the benefit of social welfare or as indolent troublemakers who occupy fertile lands which would be better used to propel the countries' expanding agribusiness (as seen in the cited Veja article) is ultimately not more harmful to their demands than simply being erased from public awareness and discourse. In fact, even reasonably well-informed Brazilians have little insight into the country’s Indian affairs, and the Pataxó of Coroa Vermelha have often argued that foreign tourists know more about their situation than domestic ones. The persistent violence against leaders of indigenous groups, for instance, probably goes as unnoticed by the general Brazilian public as the prevalent police violence in the outskirts of Lisbon in Portugal. 
The endeavour to obscure the concerns of minority groups by making them (or a certain part of their lives) invisible can be a quite deliberate act, performed by agents of national or regional state power. Packard (2008: 69), in the context of a participatory photography project in Nashville, Tennessee, points to the political relevance of seeing and being seen, and describes how authorities and the city's homeless population clashed over the latter's "right of being seen":

\footnotetext{
"In Nashville in particular, there is an ongoing effort to deal with the issue of visibility as many homeless seek to make themselves more visible to the tourists and business people who travel downtown and the city council and local government attempt to reduce their presence through efforts such as anti-panhandling legislation, a lack of public facilities, and an increase of arrests for loitering." (Packard 2008: 70)
}

While Packard engaged in helping Nashville's homeless to overcome their state of invisibility by handing out cameras, in a similar attempt during the winter of 2005-2006, the French NGO "Médecins du Monde" donated 300 shiny blue tents to clochards (vagrants) from the streets of Paris. As in Nashville, the Parisian city authorities were eager to remove the unwanted from the focus of unwanted public attention, offering temporary accommodation in boarding-houses to the (in)voluntary campers. The "visibility politics" of both city governments exemplify the degree to which the power of "making visible" or "making invisible" forms part of state power. To the same extent that words have a part in the creation of social entities ( $c f$. Bourdieu 1996 [1994]) and the state exercises, as Bourdieu remarks, "an almost divine power of creation" by articulating that a certain group, entity or being "truly exists ... in its legitimate social definition, that is, is what it is authorized to be" (ib.: 114, emphasis added), images not only visually describe (and prescribe, $c f$. Zoettl 2011a) social groups in public discourse, but may also decide a group's existence-in-public, acting as a vehicle of what one might call the state's "power to make visible".

For their part, the residents of Cova da Moura are well aware of the negative image the Portuguese population has of their neighbourhood. They frequently complain about the way Portuguese newspapers and particularly Portuguese television portray them, often using images of non-involved "generic" black people when "reporting" on security issues. As one of the rappers from Cova da Moura poetizes, "a group of white youths on the streets / are kids just having a few drinks here / a group of young blacks on the streets / is a gang going to snatch your gear" ${ }^{\prime 6}$. Visibility concerns not only the fact of simply being visible to the public,

\footnotetext{
6 "Um grupo de jovens brancos na rua / são betos que vão se embebedar / Um grupo de jovens negros na rua / são gang que vão gamar” (Kumunikasóm Suciale, Kromo Di Ghetto and Lord Strike).
} 
but also the way someone's image is perpetuated and which particular elements of an individual's culture are publicly referred to as representative of a certain group's behaviour. Juxtaposing images of external signs of ethnic identity and those of criminality and violence, for example, implicitly (that is, visually) suggests that "being criminal" may be "somehow" related to African Portuguese "culture".

In today's image-society, the power of making things seen or unseen is largely exercised by the public and private communications media. It can be conceptualised as part of a system of "symbolic power" (Bourdieu 2010 [1989]) that accounts for - to use the words of Paulo Freire - a "cultural invasion" by means of which the dominant sectors of society "impose their world-view" on the less privileged sectors (2005 [1968]: 73). Images play an important role in the consolidation of what one may call, depending on stance and circumstance, the "established order" (Bourdieu 1996 [1994]: 117) or a "world of oppression" (Freire 2005 [1968]: 201) - through a medium of non-physical "violence" which extorts "submissions which are not even perceived as such, relying on 'collective expectations' in socially inculcated beliefs" (Bourdieu 1996 [1994]: 171). In the image-society, such "collective expectations" can be shaped by collective pictorial representations, that is, images which mentally link certain concepts, ideas and entities with certain pictures. The abovementioned generic images of black people on the Lisbon streets can thus become visual representations of a (misguided) concept of "an ethnic group's disposition to delinquency" which - being perpetuated by visual media - may establish itself as the collective representation of a collective expectation. One of the Misturas interviewees, for example, quoted (off camera) a Lisbon police officer who, during court proceedings, justified the arrest of a group of residents from Cova da Moura (outside the confines of their neighbourhood) by saying that "a group of young people standing together and wearing hoodies" necessarily aroused his suspicions.

\section{Culture and empowerment}

Given their status as a "critical neighbourhood", the workshop participants' desire to counterbalance their negative public image with positively designated images from the realm of the arts seems only natural. Arlindo, one of the most assiduous participants, expressed (in 
an interview conducted a couple of months after the workshop ended $)^{7}$ his expectation that the video may eventually help to improve Cova da Moura's dubious reputation:

\begin{abstract}
"It was easy to go for the music subject, the majority of my colleagues wanted to know about music. It was a way of getting to know our own neighbourhood, to see our neighbourhood stuff from another angle. [...] I wanted to make a film with good images and good things from Cova da Moura. It was an opportunity to convey another image of our neighbourhood. [...] We don't only have problems here in our neighbourhood. There's also good stuff. [...] People don't look at the good stuff here. Many only view the problems and that's the reputation that remains." (Arlindo)
\end{abstract}

Just as Arlindo wanted to make people from the outside see "the good stuff", during our first meetings another participant, Fernando, was eager to make the point that "delinquency is not the only option" for young people who grow up in Cova da Moura. Fernando, who trains a football team in the area, therefore suggested making a film about "people who have made it big", like black players in the Portuguese national team, attempting to demonstrate to his fellow residents that, as he explained, "not everything is the system's fault".

The crux of the understandable desire of marginalized communities to show the positive, their achievements and "cultural riches" (Carelli), is its tendency to overlap with the efforts of the state and other dominant public/private groups in their glossing over of whatever, for political reasons, they consider best left unseen. Notorious police violence, severe housing problems, teenage pregnancy or the high number of early school leavers are some of the stories one may inadvertently come across in Cova da Moura or similar neighbourhoods. Needless to say, the number of professional football players that originate from the black dormitory suburbs of Lisbon is very low, and indeed a mixture of variable structural disadvantages (poor language skills, latchkey childhoods, precarious legal status, ethnicity-based prejudices, etc.) mean that the vast majority of immigrants with African roots in Portugal either work in the construction industry, if they are male, or as supermarket cashiers or cleaning ladies, if they are female.

Their underprivileged status often entails a more or less pronounced lack of selfassurance, which further hinders achievement outside the small world of their neighbourhood. Many residents of the suburbs only leave their neighbourhoods to commute to work, and people who do not have a job may not leave at all. Lisbon's city centre, just a 20-minute train ride away, seems to some a strange place, and for those who work long hours for little money

\footnotetext{
${ }^{7}$ Interviews courtesy of Catarina Laranjeiro and Catarina Vasconcelos.
} 
strolling through one of the large shopping malls that were constructed after Expo '98, when Portugal's economy was still growing, might be their only weekend entertainment. The perception of one's own and one's equals' monetary weakness may easily lead to a generalized sentiment of group inferiority, fostering the internalization of a doxa (Bourdieu 1977 [1972]) that takes an underprivileged socioeconomic status for granted. Freire highlights the importance of such a feeling of inferiority in the construction of a certain self-image and world-image which, in turn, facilitate the reproduction of unequal social structures:

\footnotetext{
"[T]hrough 'cultural invasion', the 'invaded' see their own reality through the eyes of the 'invaders' and not through their own [...] A basic condition for the success of 'cultural invasion' is the invaded's awareness of their intrinsic inferiority [...]. By recognizing themselves as 'inferior', the invaded will inevitably recognize the invader's 'superiority', and the value system of the latter will dominate the agenda of the invaded." (Freire 2005 [1968]: 174)
}

Demonstrating the richness of Capeverdean music culture was felt by the directors of Misturas to be an opportunity to regain esteem for their people and to demonstrate - to themselves and others - that they are not what they feel they are supposed to be. Similarly, most of the indigenous groups I approached in Brazil spontaneously suggested filming their dances, their agriculture or their celebrations, presumably in an attempt to be recognized by dominant society for what they understand to be a central part of their existence and identity that is, their Indianness. Presenting one's "culture" (even in the objectified sense of the word) to the dominant Other is a way not only to seek understanding and appreciation, but also to avoid being brushed aside and erased from public discourse on the basis of (visual) stigmata. Sahlins (1993: 18), discussing what he calls the failed "universalizing cultural project", quotes the Guinean independence fighter and political leader Amilcar Cabral to underline the importance of culture in the struggle between dominant and non-dominant forces:

\footnotetext{
"Culture has proven to be the very foundation of the liberation movement. Only societies which preserve their cultures are able to mobilize and organize themselves and fight against foreign domination. Whatever ideological or idealistic forms it takes, culture is essential to the historical process. [...] And since a society that really succeeds in throwing off the foreign yoke reverts to the upward path of its own culture, the struggle for liberation is above all an act of culture." (Amilcar Cabral, op cit. Sahlins 1993: 18)
}

However, even when considering the merit of participatory projects that seek to support community members in their efforts to rediscover, reaffirm and value their own way of being in relation to the norms and value judgments of dominant society, the unfortunate and generally unnoticed - complicity between the desire of marginalized communities to 
show their best side, and the wish of dominant society to conceal the (marginalized) negative, causes uneasiness. While the makers of Misturas were filming their neighbours' virtuosity with the cavaquinho (a small four-stringed guitar that sets the rhythm for the Capeverdean morna), Portuguese police officers obviously did not stop arbitrarily beating up black immigrants in the backrooms of their police stations. Neither did Brazilian pistoleiros and police officers stop chasing down north-eastern Indian leaders who take a stand for the disputed homologation of Indian Reserves simply because these Indians were learning to edit videos about their heritage, dances and ceremonies. From time to time, I felt the short-term political irrelevance of the anthropologist's doings and occasionally, like others before me, unobtrusively "tried to push the buttons" (Guidi) and provoke a more "subversive" cinematographic stance within the communities in which I was working. Naturally, I had to respect their demands and learn, as others did, that there is no shortcut from simple capacitybuilding to true political empowerment.

When working with audio-visual media, people's awareness is a key to dealing with the "structured and structuring instruments of communication" (Bourdieu) and this awareness may only be raised through a continuous process that constantly questions the way images are produced and used to convey representations that channel public discourse. While "filming culture" can be seen as a first step towards giving marginalized communities a say in their public image, it can also easily connive in their further objectivation-folclorization, once again serving the interests of the dominant sectors of society. Promoting group-specific cultural activities may (albeit unknowingly) play up to a strategy of divide et impera, a weakening of underprivileged groups, individuals and interests through their segregation into subgroups and subordinate interests, defined by means of cultural "traits". Paulo Freire was aware of the danger of well-intended "cultural action" which ultimately impedes the empowerment of its beneficiaries:

"The oppressing powers are interested in making the oppressed weaker than they already are, isolating them, creating and deepening divisions between them, through a multitude of methods and processes. These operate variously from the repressive acts of state bureaucracy which they control to the forms of cultural action through which they handle the masses, giving them the impression that they are being helped. One of the characteristics of these forms of action, which is hardly ever perceived by the benevolent, but naive, professionals who become involved, is the placing of emphasis on a localised vision of the problems and not a vision that understands them as one dimension of a totality. The more the totality of an area is broken up into 'local communities', through 'community development' projects, without studying these communities in their entirety [...] the more their alienation is reinforced. And, the more they become alienated, the easier it is to divide them and keep them divided. 
These focalized forms of action, which intensify the focalized mode of existence of the (particularly rural) oppressed masses, hamper their critical understanding of reality, and keep them isolated both from the problems of oppressed people in other areas and the dialectical relationship of these problems to their own." (161f)

In this way, the special political attention the present Brazilian Government's pays to communities such as Indians, quilombolas, extrativistas (gatherers), ribeirinhas (riverside dwellers), tradicionais (traditional peoples), which all have special programmes that seek their economic as well as cultural promotion could - arguably - be criticised for potentially preventing awareness of the common causes of their socioeconomic marginalization. The ongoing increased funding levels for cultural (and other) projects from which certain groups benefit and others do not, may indeed foster a segregation of the interests of underprivileged citizens who share a good deal of their structural disadvantages (e.g. lack of land ownership). Freire - who as an educator defended a very critical standpoint in relation to "humanitarism" (as opposed to humanism) (ib.: 45) - advises against certain welfare-based forms of cultural action that "act as anaesthetics" and "distract the masses from the real cause as much as from the precise solution of their problems", dividing them into "groups of individuals who wait to receive more than others" (ib.: 172).

However, seen from a broader perspective as part of an educational awareness-raising process, participatory video can be a valuable tool for a shared anthropology which seeks the better understanding and more profound involvement of the people with whom it is concerned. When working together, for days or weeks, on a film, the inescapable need to discuss the anthropologist's and the community's vision of the cinematic raw material leads to an improved mutual understanding of the diverging frameworks which the researcher and the researched apply to the same reality. And what may initially seem to be of little political importance or benefit to a community, may in the long run be the first stimulus to true empowerment on an individual and group level that develops its own dynamics. While still editing the funeral urns video, the Hã-Hã-Hãe were already brainstorming other potential uses of their growing audiovisual capabilities. Next time they would surely catch on camera the gunmen who had, a couple of weeks previously and in the dead of night, randomly fired in their direction from a shack near the village. And the more than two million hits of a site like Índios Online ${ }^{8}$, whose contents are produced entirely by Brazilian indigenous people, demonstrates that Turner (1992) rightfully criticises James Faris for underestimating indigenous peoples' capacity to appropriate a dominant society's techniques for their own

\footnotetext{
${ }^{8} \mathrm{Http}: / / w w w . i n d i o s o n l i n e . o r g . b r$
} 
purposes ( $c f$. Faris 1992). While I was discussing with the Hã-Hã-Hãe what scenes to edit into the final film, news reached them (via the internet) that the legal representative of Índios Online would face litigation by local landowners who were concerned about other Indian videos hosted by the site, asserting their "right of image" - another (if somewhat disturbing) sign that our doings, in the end, might have more political relevance than we had originally hoped.

\section{References}

Amnesty International. 2011. "Report 2011 - Portugal.” London. Retrieved July 11, 2011 (http://www.amnesty.org/en/region/portugal/report-2010).

Anderson, Benedict. 2006 [1983]. Imagined communities. London, New York: Verso.

Barth, Frederik. 1969. Ethnic groups and boundaries. The social organization of culture difference. Bergen-Oslo \& London: Universitets Forlaget; Allen and Unwin.

Bentes, Ivana 2006. "Câmera muy very good pra mim trabalhar." in Catálogo da «Mostra Vídeo nas Aldeias: Um Olhar Indígena». Rio de Janeiro.

Bourdieu, Pierre. 1977 [1972]. Outline of a theory of practice [Esquisse d'une théorie de la pratique]. Cambridge: Cambridge University Press.

Bourdieu, Pierre. 1996 [1994]. Razões Práticas: Sobre a teoria da ação. Campinas: Papirus Editora.

Bourdieu, Pierre. 2010 [1989]. O poder simbólico. Rio de Janeiro: Bertrand Brasil.

Carelli, Vincent 2006. "Moi, un Indien." in Catálogo da «Mostra Vídeo nas Aldeias: Um Olhar Indígena». Rio de Janeiro.

Comaroff, John and Jean Comaroff. 2009. Ethnicity, Inc. Chicago and London: The University of Chicago Press.

Corrêa, Mari 2006a. "Conversa a cinco." in Catálogo da «Mostra Vídeo nas Aldeias: Um Olhar Indígena». Rio de Janeiro.

Coutinho, Leonardo, Igor Paulin, and Júlia d. Medeiros. 2010. "A farra da antropologia oportunista." Veja, Maio 5, pp. 154-161. 
Crocker, Stephen 2003. "The 'Fogo Process': participatory communication in a globalizing world." Pp. 122-141 in Participatory video: images that transform and empower. New Delhi: Sage Publications.

Cunha, Manuela C. d. 2009. Cultura com aspas e outros ensaios. São Paulo: Cosac Naify.

Dowmunt, Tony 2007. "Introduction.” Pp. 12-20 in Inclusion through media, edited by Tony Dowmunt, Mark Dunford, and Nicole van Hemert. London: Goldsmith, University of London.

Faris, James C. 1992. "Anthropological transparency: film, representation and politics." Pp. 171-182 in Film as Ethnography, edited by Peter Ian Crawford and David Turton. Manchester: Manchester University Press.

Fergusson, Russel e. a., ed. 1990. Out there. Marginalization and contemporary cultures. Cambridge, MA: MIT Press.

Freire, Paulo. 2005 [1968]. Pedagogia do oprimido. Rio de Janeiro: Paz e Terra.

Gadihoke, Sabeena 2003. "The struggle to "empower": a women behind the camera." Pp. 271-285 in Participatory video: images that transform and empower. New Delhi: Sage Publications.

Ginsburg, Faye 2002. "Mediating culture: indigenous media, ethnographic film, and the production of identity." Pp. 187-209 in The anthropology of media: a reader. Malden: Blackwell.

Guidi, Padma 2003. “Guatemalan Mayan women and participatory visual media.” Pp. 252-270 in Participatory video: images that transform and empower, edited by Shirley White. New Delhi: Sage Publications.

Hooks, Bell 1990. "Marginality as a site of resistance.” Pp. 341-344 in Out there. Marginalization and contemporary cultures, edited by Russel Fergusson et al. Cambridge, MA: MIT Press.

IHRU (Instituto da Habitação e da Reabilitação Urbana). 2011a. "Apresentação da Iniciativa Bairros Críticos.” Portal da Habitação. Retrieved Mai 18, 2011 (http://www.portaldahabitacao.pt/pt/ibc/multimedia/video_apresentacao_ibc.html). 
IHRU (Instituto da Habitação e da Reabilitação Urbana). 2011b. "Iniciativa Bairros $\begin{array}{lllll}\text { Críticos.” } & \text { Apresentação. } & \text { Retrieved } & \text { Mai } & 16,\end{array}$ (http://www.portaldahabitacao.pt/pt/ibc/apresentacao/).

Melatti, Julio C. 2007 [1970]. Índios do Brasil. São Paulo: edusp.

Oliveira, João P. d. 2004. A viagem da volta. Etnicidade, política e reelaboração cultural no Nordeste indígena. $2^{\text {nd }}$ ed. Rio de Janeiro: Contra Capa.

Packard, Josh. 2008. 'I'm gonna show you what it's really like out here': the power and limitation of participatory visual methods." Visual Studies Vol. 23(1):63-77.

Pink, Sarah. 2001. "More visualising, more methodologies: on video, reflexivity and qualitative research.” The Sociological Review 586-599.

Ramella, Marcelo and Gonzalo Olmos. 2005. "Participant Authored Audiovisual Stories (PAAS): Giving the camera away or giving the camera a way?" (10 Qualitative Series).

Sahlins, Marshall. 1993. "Goodbye to Tristes Tropes: Ethnography in the context of modem world history." Journal of Modern History (65):1-25.

Sahlins, Marshall 2000. "Cosmologies of Capitalism: The trans-pacific sector of »The World System«.” Pp. 415-469 in Culture in practice. Selected essays. New York: Zone Books.

Scott, James. 1985. Weapons of the weak: everyday forms of peasant resistance. New Haven: Yale Univ. Press.

Turner, Terence. 1992. "Defiant images: the Kayapo appropriation of video." Anthropology Today Vol. 8(6):5-16.

White, Shirley, ed. 2003. Participatory video: images that transform and empower. New Delhi: Sage Publications.

Zoettl, Peter A. 2011a. "Imagens do nordeste, nordeste das imagens. Notas de campo sobre o poder de nomeação, o 'vídeo participativo' e a imagem quilombola." Cadernos do Leme Vol. 3(1):71-85.

Zoettl, Peter A. 2011b. “'Participatory Video' as a means of reflection and selfreflection about the image and identity of reemerging indigenous groups in northeastern Brazil.” Espaço Ameríndio [in press] Vol. 5(2). 